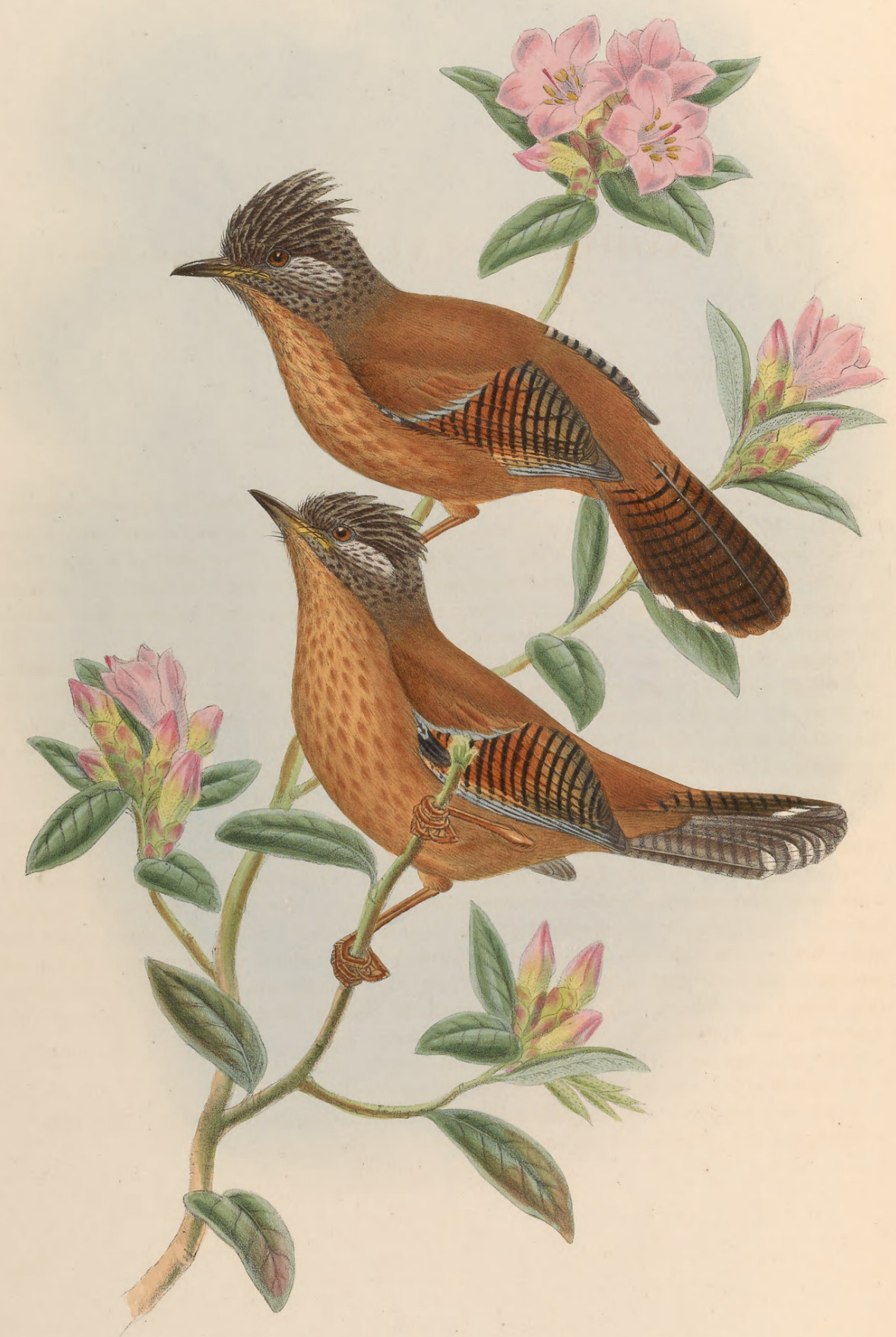




\title{
ACTINODURA WALDENI, Godwin-Austen.
}

\author{
Walden's Actinodura.
}

Actinodura Waldeni, Godwin-Austen, P. Z. S., 1874, p. 46, pl. xii.

Thrs third species of the genus Actinodura is one of the recent discoveries made by Major Godwin-Austen in the Nágá Hills; and on reference to the Plates given in the present work a casual observer will perceive at once its specific distinctness. In its shorter tail and general coloration the present bird is most like the A. nipalensis ; but the feathers of the breast, every one of which is centred with brown, are a very striking and characteristic feature in the new form. All three are elegant and harmoniously coloured little birds, rich brown and chocolate-brown being the predominant tints.

Of course the time will come when we shall know as much about the habits and economy of Actinodura as we do about Accentor and other European forms; and it would be interesting to know whether these birds are gifted with song, as is the case with so many of these sombre-coloured birds. This we have to learn from the researches of future observers; but, judging from its bill, I should imagine that they were not very highly gifted as songsters. Dr. Jerdon places Actinodura in the Timaline, close to Trochalopteron and Sibia; but from their barred wings and tail they apparently show some affinity to the Troglodytince.

Major Godwin-Austen is at present the only ornithologist who has met with this bird, and I am indebted to him for the loan of the typical specimen. The following is his original description :-

"Head full-crested, extending back for more than an inch, hoary grey, edged pale; back rich brown with a greenish hue, becoming more rufous on the rump and upper tail-coverts; base of tail-feathers chestnut, for half their length narrowly barred with black, then black for terminal inch, the three outer tipped white; quills black, outer web chestnut at base, then barred with black, and the narrow terminal portion grey; primary coverts black, the winglet-feathers grey, barred black; ear-coverts hoary; side of head hair-grey; chin, breast, and abdomen rufous brown, paler on the chin and throat, the whole having a streaky appearance, the feathers being centred with a darker shade.

"Bill grey; legs and feet fleshy brown; irides pale grey.

"Length 8 inches, wing $3 \cdot 48$, tail $3 \cdot 45$, tarsus $1 \cdot 2$, bill at front $0 \cdot 62$.

"I first shot this bird on the Peak of Japvo, at about 9000 feet, on the Burrail range, Nágá Hills."

The figures in the Plate are of the natural size. 


\section{$2 \mathrm{BHL}$ Biodiversity Heritage Library}

Gould, John. 1875. "Walden's Actinodura, Actinodura waldeni, Godwin-Austin. [PI. 58]." The Birds of Asia 3(XXVII), -. https://doi.org/10.5962/p.323037.

View This Item Online: https://www.biodiversitylibrary.org/item/118635

DOI: https://doi.org/10.5962/p.323037

Permalink: https://www.biodiversitylibrary.org/partpdf/323037

\section{Holding Institution}

Smithsonian Libraries

\section{Sponsored by}

Smithsonian Institution Libraries

\section{Copyright \& Reuse}

Copyright Status: Not in copyright

This document was created from content at the Biodiversity Heritage Library, the world's largest open access digital library for biodiversity literature and archives. Visit BHL at https://www.biodiversitylibrary.org. 